\title{
Phonological Characteristics of Early Lexicon in Korean-Acquiring Children
}

\author{
Seunghee $\mathrm{Ha}^{\mathrm{a}}$, Minkyeong $\mathrm{Pi}^{\mathrm{b}}$ \\ ${ }^{a}$ Division of Speech Pathology and Audiology, Audiology and Speech Pathology Research Institute, Hallym University, Chuncheon, Korea \\ ${ }^{b}$ Graduate Program in Speech Language Pathology, Hallym University, Chuncheon, Korea
}

\author{
Correspondence: Seunghee $\mathrm{Ha}, \mathrm{PhD}$ \\ Division of Speech Pathology and Audiology, \\ Audiology and Speech Pathology Research \\ Institute, Hallym University, 1 Hallimdaehak-gil, \\ Chuncheon 24252, Korea \\ Tel: $+82-33-248-2215$ \\ Fax: +82-33-256-3420 \\ E-mail: shha@hallym.ac.kr
}

Received: October 12, 2018

Revised: November 16, 2018

Accepted: November 29, 2018
Objectives: There are bi-directional links between phonological and lexical development in early language acquisition. This study analyzed phonological characteristics of words which 12- to 30-month-old children produced as recorded by parent reports, as well as early lexicons in Korean version MacArthur-Bates Communicative Development Inventories (KM-B CDI). Methods: The frequency of phonemes and word structures in all the words in the K M-B CDI were analyzed. The K M-B CDI was administrated to parents of 193 children. The groups were divided into the three age groups: 12-17 months, 18-23 months, and $24-30$ months. Word lists acquired by $50 \%$ to $75 \%$ of children in the three age groups were phonemically transcribed and then the frequency of phonemes, consonants types in the initial position, and word structures were analyzed for each age group. Results: The most common word shapes in the K M-B CDI were CVCV and CVC, and were either disyllables or monosyllables. The most common phonemes of words in the KM-B CDI were /l, k, n, a, $\mathrm{i} /$. Seventy-five percent of children aged 12-17 months produced only words with $/ \mathrm{m} /$ and $/ \mathrm{p}^{*} /$, which start with either a vowel or nasal. The two groups below 24 months produced the VCV words shape most frequently. As children expand their expressive vocabulary with age, the number of phoneme types produced, the percentage of words starting with stops, and the word shape inventory increased. Conclusion: This study showed the phonological characteristics of early lexicon in Korean-acquiring children, which have implications in selecting target words for intervention considering both early phonological and lexical development.

Keywords: Early lexicon, Phonological characteristic, Parent report, Korean-acquiring children
아동이 언어를 습득하는 초기 단계에는 음운, 어휘, 구문, 문법적 인 요소가 서로 긴밀한 관계를 보이면서 발달해 나간다. 특히 음운 과 어휘 발달 영역에서는 양방향적인 상호관계를 보이며, 음운 능 력이 어휘 습득에 영향을 주고 어휘의 특성과 구조가 음운 지식에 영향을 준다. 음운과 어휘 간의 관계를 방대한 양의 문헌을 토대로 심층적으로 정리한 Stoel-Gammon (2011)은 이러한 음운과 어휘 간의 양방향적인 관계가 아동이 출생부터 4 세에 이르기까지 관찰 된다고 정리하였다. 특히 2세 6 개월 이전까지는 어휘가 음운 발달 에 영향을 끼치는 정도보다 발달해 가는 음운 체계가 어휘 습득에 더 큰 영향을 끼친다고 하였다.

최근 국내연구에서도 1 세 후반이나 2 세 아동들이 음운과 어휘
능력상의 긴밀한 관계를 보이면서 발달해 감을 보여주고 있다(Choi, Kim, \& Kim, 2014; Ha, Seol, So, \& Pae, 2016; Pi \& Ha, 2018). 한 예 로 $\mathrm{Pi}$ 와 $\mathrm{Ha}$ (2018)는 18-30개월 한국 일반아동의 자발화를 분석하 여 음운, 어휘, 문법 능력을 나타내는 지표를 통해 언어 영역 간의 관계를 살펴보았다. 연구결과, 대상 아동들은 대다수의 음운, 어휘 지표 간의 유의미한 상관관계를 보였다. 특히 $18-24$ 개월 아동은 목 표 낱말의 구조와 분절음에 근접한 정확한 조음음운 능력을 보이 는 아동일수록 자발화에서 구사하는 어휘 수가 증가하는 유의한 정적 상관관계를 보였다. 이러한 선행연구는 초기 언어발달 단계에 있는 아동을 중재할 때 음운 또는 어휘 한 영역에만 초점을 맞추는 중재보다는 음운과 어휘 또는 구문 영역 간의 유기적인 관계를 고 
려하면서 전체적인 아동의 말-언어발달을 촉진하는 포괄적인 중재 가 보다 더 효과적일 수 있음을 제안하고 있다.

음운과 어휘 간의 긴밀한 관계는 언어이전기 발성에서부터 관찰 되는데, 여러 연구가 초기 발성, 특히 생후 6개월 이후에 산출되는 음절성 발성 형태가 초기 어휘의 음운 패턴과 구조의 기저를 이루 고 있음을 보여주었다(Bernhardt \& Stoel-Gammon, 1996; Oller, Wieman, Doyle, \& Ross, 1976; Stoel-Gammon, 2011). 말늦은 아동 의 경우 이러한 음운과 어휘 발달상의 긴밀한 관계가 언어기뿐만 아니라 언어이전기에도 관찰되는 대표적인 집단이다. 1 세 6 개월에 10 개 미만으로, 2 세에는 50 개 미만의 표현 어휘를 보일 경우 일반적 으로 말늦은 아동으로 분류된다(Paul \& Jennings, 1992; Rescorla \& Ratner, 1996; Stoel-Gammon, 1991). 이러한 초기 표현 어휘 발달 상의 지연이 두드러지게 나타나는 말늦은 아동은 초기 발성 시기 에서부터 일반아동과 비교해 음절성 옹알이의 출현이 늦고, 발성 내 자음 목록이 적고 단순한음절 구조를 보인다. 이와 비슷한 특징 이 구개열 아동에게서도 관찰되는데 Chapman, Hardin-Jones와 Halter (2003)에서는 언어이전기에 CV 음절과 파열음을 포함한 음 절을 많이 산출하는 구개열 아동일수록 구개성형술 이후 낱말 출 현이 일찍 이루어지고 어휘 발달이 보다 빠르게 이루어졌다. 즉 초 기 발성에서 관찰되는 음운상의 제한이 이후 본격적인 언어발달이 이루어지는 시기에 음운과 어휘상의 제한으로 이어져서 나타난다. 따라서 음운과 표현 어휘상의 지연이나 문제를 동시에 보일 가능성 이 높은 말 늦은 아동이나 구개열 아동의 경우에는 이 영역 간의 관 계를 고려한 중재가 보다 더 효과적일 것이다.

$\mathrm{Ha}$ 와 $\mathrm{Pi}$ (2016)는 18-30개월 한국 아동의 자발화를 토대로 자음 유형별 산출빈도와 어절의 첫소리 특성을 살펴봄으로써 말소리 산 출상의 문제를 보이는 아동을 중재할 때 목표 음소를 선정하고, 음 소 산출상의 제약으로 인해 어휘 발달에도 지연이나 특이한 점을 보이는지 살펴볼 수 있는 근거자료를 마련하였다. $\mathrm{Ha}$ 와 $\mathrm{Pi}$ (2016)의 연구는 초기 음운 습득 단계에 있는 일반아동의 실제 발화를 음성 전사하여 한국어 말소리 빈도와 어절의 첫소리 특징을 살펴보았기 때문에 3 세 이전 아동의 말 평가와 중재에 시사하는 바가 크다. 하 지만 제한된 상호작용 맥락에서 수집된 아동의 자유 발화를 토대 로 분석된 자료이기 때문에 대표성이 떨어질 수 있다. 또한 목표 어 휘의 성인 형태가 아닌 아동이 실제로 발음한 말 샘플의 음성 전사 를 토대로 말소리 빈도를 살펴보았기 때문에 아동이 실제로 의도한 어휘와 차이가 있을 수 있고, 아동의 말운동학적 발달 수준에 영향 을 받은 자료라 할 수 있다. 따라서 아동이 실제로 발음한 형태에서 확인된 말소리 빈도 및 음절 구조에 대한 정보와 함께 일상생활에 서 아동의 양육자가 확인한 어휘를 토대로 음운 특성을 제시한 자
료를 살펴본다면 초기 어휘 및 음운 발달에 대한 보다 더 포괄적인 이해를 갖출수 있을 것이다. 즉 성인의 목표 형태와 아동의 실제 발 음 형태를 동시에 고려하여 중재 목표 음소와 어휘를 선정하는 것 이 더 적절하다. 음운과 어휘의 양방향적인 상호관계는 아동의 어 휘 습득 수준이 50개 정도일 때 가장 두드러지게 나타난다(Estrem \& Broen, 1989). 따라서 일반아동이 낱말 50개를 일반적으로 습득, 산출하는 시기에 해당하는 18-24개월을 기준으로 전-중-후에 있 는 어린 아동들의 표현 어휘상에 나타난 음운 특징과 구조에 대한 정보를 갖추는 것이 필요하다.

초기 언어발달에 음운과 어휘 간의 관계를 강조하면서 Stoel-Gammon (1998)은 미국판 어휘 체크리스트인 MacArthur Communicative Development Inventories (MCDI; Fenson et al., 1993)에 포 함된 596개의 낱말의 음운 특성을 분석하였다. 분석 결과 전체 낱 말의 $60 \%$ 가 1 음절이고 $35 \%$ 가 2음절이며, 2 음절 이상의 낱말의 $90 \%$ 가 첫 음절에 강세가 있는 것으로 나타났다. 또한 초기 영어 어 휘의 가장 보편적인 낱말 구조는 CVC와 CVCV이며, 전체 낱말의 $57 \%$ 가 파열음으로 시작하였으며 특히 /b/로 시작하는 낱말의 비 율이 상당히 높았다. /b/로 시작하는 낱말이 성인 어휘에는 $5 \%$ 정 도였으나, 어휘 습득 수준이 100 낱말 이하인 아동의 경우에는 /b/ 로 시작하는 낱말이 전체 낱말의 $22 \%$ 를 차지하였다. Stoel-Gam$\operatorname{mon}$ (1998)은 이러한 /b/로 시작하는 낱말이 상대적으로 높은 비 율을 차지하는 현상을 영어를 습득하는 어린 아동에게 관찰되는 “특정 어휘를 선택하는 패턴(lexical selection pattern)"의 대표적인 예라고 설명하였다.

국내에서 현재 영유아용 어휘 체크리스트로 사용되고 있는 한국 판 맥아더-베이츠 의사소통발달평가(Korean version MacArthurBates Communicative Development Inventories, K M-B CDI; Pae \& Kwak, 2011)는 Pae (1993)의 연구에서 MCDI (Fenson et al., 1993) 중 유아용의 어휘 부분을 사용한 것에서 시작하여 지속적인 수정 과 전국적 규모의 어휘표준화 작업을 통해 개발되었다. 검사도구가 개발된 이래로 임상현장에서 36 개월 미만의 영유아나 제한적인 언 어발달을 보이는 아동들의 언어평가에 활발하게 사용되고 있다. 또한 일반 영유아를 비롯해서 언어발달지체, 자폐스펙트럼, 청각장 애, 다문화가정 아동 등 다양한 아동들을 대상으로 한 많은 어휘 발달 및 중재 연구에 평가도구로 사용되고 있다(Pae, Kwak, Kim, Jung, \& Kim, 2009; Pae \& Kim, 2010; Park \& Pae, 2003; Shin \& Lee, 2008). K M-B CDI에 포함된 어휘에 대한 연구는 현재까지 어 휘 범주나 개념 분포 특성에 국한되어 있을 뿐 음운 특성에 대한 연 구는 아직 이루어지지 않았다. 따라서 K M-B CDI에 포함된 어휘 의 음운 특성에 대한 분석이 필요하다. 
초기 어휘에 대한 음운 분석은 아동이 산출해야 하는 어휘의 목 표 형태의 틀과 음운 정보를 제공하고, 이러한 정보는 음운과 어휘 상의 발달이 지연된 아동을 위한 중재에서 목표 어휘를 선정할 때 참조할 수 있는 근거자료가 된다. 또한 아동의 음운과 어휘를 습득 해 가는 과정과 특성에 대한 이해를 넓히게 될 것이다. 따라서 본 연 구는 K M-B CDI를 이용하여 부모 보고에 따른 12-30개월 일반아 동이 습득한 어휘 목록에 나타난 음운 특성을 살펴보고자 하였다. 실제 수집된 자료를 분석하기에 앞서, 한국 아동의 기본적인 어휘 특성을 전체적으로 살펴보고자 K M-B CDI에 포함된 어휘의 음운 특성을 분석하였다. 이후 언어발달 수준에 따라 어휘와 음운 특성 을 자세히 살펴보기 위해 일반아동을 12-17개월, 18-23개월, 24-30 개월의 월령 집단으로 나누어 해당 집단의 절반 이상이 표현한다고 보고된 어휘를 토대로 말소리 출현 빈도와음절 구조를 살펴보았다.

\section{연구방법}

\section{대상자}

본 연구는 (1) 부모에 의해 뚜렷한 인지, 신경, 발달과 관련된 의학 적 진단을 받지 않았다고 보고되었으며, (2) 영아선별 교육진단검 사(DEP; Jang, Seo, \& Ha, 2008)에서 전체 영역이 백분위 $35 \%$ ile 이 상 $(\mathrm{DEP}$ 검사 도구에서는 0-20\%ile이 '매우 느림', 20-35\%ile은 '느 림', 35-65\%ile은 ‘보통', 65-80\%ile은 ‘빠름', 80-100\%ile은 ‘매우 빠 름으로 분류함), (3) 영유아 언어발달검사(SELSI; Kim, Kim, Yoon, $\& \mathrm{Kim}, 2003)$ 결과, -1 SD 이상으로 정상 발달하는 12-30개월 아동 193 명(남 88명, 여 105명)을 대상으로 하였다. 발달 양상을 살펴보기 위해 월령 집단을 3개로 구분하였다(12-17개월, 18-23개월, 24-30 개월). 전체 대상자의 월령 집단별 성비와 인원 및 K M-B CDI로 보 고된 표현 어휘 수를 Table 1 에 제시하였다.

\section{자료 수집}

연구 절차는 한림대학교 생명윤리위원회의 승인(IRB No. 2016078-1-C)을 받아 진행되었다. 대상 아동의 양육자에게 한국판 맥아
더-베이츠 의사소통발달 평가(K M-B CDI)를 제공하였다. K M-B CDI는 8-17개월 아동을 위한 영아용과 18-36개월 아동을 위한 유 아용으로 나뉘어 있다. 따라서 아동의 월령에 따라 12-17개월 아동 양육자에게는 영아용, 18-30개월 아동에게 양육자에게는 유아용 을 지급하였다. 그 다음 아동의 보호자에게 K M-B CDI 영아용 279 개 어휘, 유아용의 전체 항목은 641개 어휘에 대해 현재 아동이 표 현하는 낱말을 모두 표시하도록 요청하였다.

\section{자료 분석}

자료 선정은 양육자 보고에 의해 조사된 K M-B CDI 영아용(8-17 개월용) 279개 항목과 유아용(18-36개월) 641개 항목 중 문법형태 소 부분을 제외한 어휘로 이루어졌다. 예를 들어 K M-B CDI 영아 용 중 '기능어' 12 개와 표현 항목을 조사하지 않는 '일상생활과 관 련된 말' 중 5개(예: 곤지곤지, 잼잼 등)는 분석 자료에서 제외하였 다. K M-B CDI 유아용 중 '끝 맺는 말' 12 개, '조사' 12 개, '돕는 말' 6 개도 마찬가지로 분석 자료에서 제외하였다. 또한 검사지에서 병 기된 어휘는 두 산출 형태를 독립적인 것으로 보고 각각 목록에 포 함하였다(예: '과자/까까' 항목에 체크가 되어있는 경우 '과자'와 '까 까'를 모두 산출하였다는 가정하에 둘 다 단어 목록에 넣음). 따라 서 연구 자료에 포함된 총 낱말 수는 K M-B CDI 영아용의 낱말 279 개 중 제외된 어휘 17 개를 뺀 뒤, 병기된 어휘 24 개를 더한 286 개 였다. K M-B CDI 유아용 낱말 641개 중 제외된 어휘 33개를 뺀 뒤, 병기된 어휘 15 개를 더한 623 개였다.

선정된 어휘 항목을 토대로 개별 아동이 표현한다고 양육자가 보고한 모든 낱말을 목록으로 작성하였다. 자료 코딩은 언어병리학 전공 학부생 4 명이 진행하였으며, $\mathrm{K} \mathrm{M-B} \mathrm{CDI의} \mathrm{낱말을} \mathrm{엑셀에} \mathrm{입}$ 력한 뒤 해당 아동이 표현한다고 보고된 어휘는 1 , 그렇지 않은 어 휘는 0 으로 코딩하였다.

자료 분석은 $12-30$ 개월 아동의 과반수 이상에서 보고된 단어를 바탕으로 실시하였다. 단어는 월령 집단별 $75 \%$ 이상이 공통적으로 사용하는 어휘와 $50 \%$ 이상 아동이 공통적으로 사용한다고 보고 된 어휘를 나누어 살펴보았다. $75 \%$ 이상은 $12-17$ 개월 아동 집단에

Table 1. Participants' information

\begin{tabular}{lcccc}
\hline & \multicolumn{3}{c}{ Age group (mo) } \\
\cline { 2 - 5 } & $12-17(\mathrm{~N}=89)$ & $18-23(\mathrm{~N}=73)$ & $24-30(\mathrm{~N}=30)$ & Total $(\mathrm{N}=192)$ \\
\hline Sex & 42 & 33 & 12 & 87 \\
$\quad$ Male & 47 & 40 & 18 & 105 \\
$\quad$ Female & $27.31 \pm 51.20(0-286)$ & $128.64 \pm 152.54(0-618)$ & $357.83 \pm 175.24(83-608)$ & $117.93 \pm 163.27(0-618)$ \\
Number of expressive vocabulary &
\end{tabular}

Values are presented as mean \pm SD (range). 
서 67명 이상, 18 -24개월 아동 집단은 55명 이상, 25-30개월 아동 집 단은 23명 이상으로 보고된 낱말을 기준으로 하였다. $50 \%$ 이상은 12-17개월 아동 집단에서 45명 이상, 18 -24개월 아동 집단은 37명 이상 보고된 낱말, 25-30개월 아동 집단은 15 명 이상으로 보았다.

음운 특성은 전체 말소리 빈도, 낱말 첫 말소리 유형 비율, 낱말 구조를 분석하였다. 음운 특성을 분석하기 위해서 먼저 과반수 이 상 아동이 표현한다고 보고된 어휘를 자연스러운 발음 형태로 음 성 전사를 실시하였다(예: '택시' $\rightarrow$ [택씨]). 또한 아동이 일상생활에 서 산출하는 발음 형태를 고려하여 일부 $\mathrm{w}$ 계 활음은 단순화된 형 태로 전사하였다(예: 줘/조, 안돼/안대).

고빈도 50개 낱말의 음운 전사를 토대로 음소 산출 빈도를 구하 였다. 분석에는 통합형 한국어 처리 프로그램(SynKDI 5.2)을 사용 하였다. 단어의 첫 말소리 유형은 장애음(파열음, 파찰음, 마찰음), 공명자음(비음, 유음), 모음으로 나누어 살펴보았다. 또한 낱말 구 조 유형을 분석하였다. 낱말 구조 유형은 음운 전사를 기준으로 자 음 $(\mathrm{C})$, 모음 $(\mathrm{V})$, 활음 $(\mathrm{G})$ 을 표기하였다. 이 중 동일한 자음이 연속 되는 겹자음의 경우는 음성학적으로 하나의 조음 제스쳐에서 산 출되는 점을 고려하여(Yang, 2005) 자음 하나로 분석하였다(예:/엄 마/의 음절구조는 $\mathrm{VCV})$.

\section{신뢰도}

개별 아동이 표현한 낱말을 목록으로 작성할 때에 코딩의 정확 성을 파악하기 위해 전체 자료의 약 $10 \%$ ( 20 명 아동 자료)를 임의로 선정하여 코딩 신뢰도를 구하였다. 신뢰도 분석을 위한 코딩은 제2 저자가 독립적으로 실시하였다. 코딩 신뢰도를 (코딩이 일치한 단 어 수)/(전체 단어 수) $\times 100$ 으로 계산한 결과, $99.49 \%$ 로 나타났다.

음운 전사의 정확성을 파악하기 위해 제 2 저자와 언어병리학전 공 대학원생이 KM-B CDI 단어를 독립적으로 전사하여 전사자 간 신뢰도를 구하였다. 전사자 간 신뢰도는 (전사가 일치한 단어 수)/ (K M-B CDI 영아용과 유아용의 전체 단어 수)로 구하였다. 그 결

Table 2. Number of syllables of vocabulary in K M-B CDI

\begin{tabular}{lcc}
\hline & Infant (8-17 mo) & Toddler (18-36 mo) \\
\hline Number of words & 286 & 623 \\
1 syllable & $87(30.42)$ & $122(19.58)$ \\
2 syllables & $149(52.10)$ & $344(55.22)$ \\
3 syllables & $42(14.69)$ & $129(20.71)$ \\
4 syllables & $7(2.45)$ & $26(4.17)$ \\
5 syllables & $1(.35)$ & $2(.32)$
\end{tabular}

Values are presented as number (\%).

$\mathrm{K}$ M-B CDI=Korean version of MacArthur-Bates Communicative Development Inventories (Pae \& Kwak, 2011).
과 전사자 간 신뢰도는 $94.72 \%$ 였다.

\section{연구결과}

\section{$\mathrm{K} \mathrm{M}-\mathrm{B}$ CDI 전체 어휘 목록의 음운 특성}

$12-30$ 개월 한국 아동이 표현하는 어휘 목록의 음운 특성을 살펴 보기에 앞서 K M-B CDI에 수록된 어휘의 음운 특성을 분석하였 다. Table 2는 K M-B CDI 영아용과 유아용 검사지에 수록된 어휘 의 음절수에 대한 정보이다. K M-B CDI 영아용에 수록된 낱말 중 문법형태소를 제외하고 전체 단어의 개수는 286개였다. 이 중 2음 절어가 149 개로 가장 많았으며, 1 음절어 87 개, 3 음절어 42 개, 4 음절 어 7 개, 5 음절어 1 개 순으로 나타났다. K M-B CDI 유아용 검사지 도 마찬가지로 623 개 낱말 중 2 음절어가 344 개로 가장 많았으며, 3 음절어는 129 개, 1 음절어는 122 개, 4 음절어는 26 개, 5 음절어는 2 개 순으로 나타났다.

\section{$\mathrm{KM}-\mathrm{B}$ CDI 말소리 출현 빈도}

먼저 K M-B CDI 영아용의 음운 특성을 살펴보았다. 영아용 기 록지에 제시된 286개 어휘의 말소리 비율을 Appendix 1에 제시하 였다. K M-B CDI 영아용의 전체 자음은 총 18 개였는데 이는 초성 자음/ㅉ/가 나타나지 않았기 때문이다. KM-B CDI 영아용의 말소 리 고빈도 5 개를 Table 3 에 제시하였다. 전체 자음의 상위 5 개 자음 은/ㄱ/,/ㄹ/,/ㄴ/,/ㅁ/,/ㅂ/였다. 초성 자음은 /찌를 제외한 17 개 중 고빈도 음소 5 개가 / ㄱ/, /ㅁ/, /ㅂ/, / ㅅ/, / ㄴ/ 순으로 나타났다. 종성 자음은 7 개 모두가 출현하였으며 /O/,/2ᄅ/,/L/,/ㄱ/,/ㅁ/ 순이었다. 단모음 7 개 중 빈번하게 출현한 것은///,///,/工止였다.

다음으로 K M-B CDI 유아용에 제시된 어휘의 모든 말소리의 비 율을 Appendix 2에 제시하였다. K M-B CDI 유아용의 말소리 고빈 도 5 개를 Table 4에 제시하였다. 유아용 낱말 623 개 중 전체 자음은 총 19 개 출현하였으며 /ㄹ/,/ ᄀ//, / L/, / ㅁ/,/O/ 순으로 나타났다. 초

Table 3. Percentage of phonemes in K M-B CDI for infants

\begin{tabular}{|c|c|c|c|c|c|c|c|c|}
\hline \multirow{3}{*}{ Rank } & \multicolumn{6}{|c|}{ Consonants } & \multirow{2}{*}{\multicolumn{2}{|c|}{ Vowels }} \\
\hline & \multicolumn{2}{|c|}{ Total } & \multicolumn{2}{|c|}{ Initial } & \multicolumn{2}{|c|}{ Final } & & \\
\hline & Type & $\%$ & Type & $\%$ & Type & $\%$ & Type & $\%$ \\
\hline 1 & ᄀ & 14.00 & ᄀ & 14.10 & $\circ$ & 28.57 & t & 32.29 \\
\hline 2 & e & 10.89 & $\square$ & 10.47 & e & 21.14 & I & 19.50 \\
\hline 3 & ᄂ & 10.58 & $\forall$ & 10.47 & ᄂ & 17.71 & $\perp$ & 13.84 \\
\hline 4 & 口 & 10.42 & $\curlywedge$ & 8.97 & \urcorner & 13.71 & $t$ & 13.63 \\
\hline 5 & $\forall$ & 8.86 & \llcorner & 7.91 & $\square$ & 10.29 & $\top$ & 9.01 \\
\hline
\end{tabular}

$\mathrm{K}$ M-B CDI=Korean version of MacArthur-Bates Communicative Development Inventories (Pae \& Kwak, 2011). 
Table 4. Percentage of phonemes in K M-B CDI for toddlers

\begin{tabular}{|c|c|c|c|c|c|c|c|c|}
\hline \multirow{3}{*}{ Rank } & \multicolumn{6}{|c|}{ Consonants } & \multirow{2}{*}{\multicolumn{2}{|c|}{ Vowels }} \\
\hline & \multicolumn{2}{|c|}{ Total } & \multicolumn{2}{|c|}{ Initial } & \multicolumn{2}{|c|}{ Final } & & \\
\hline & Type & $\%$ & Type & $\%$ & Type & $\%$ & Type & $\%$ \\
\hline 1 & e & 14.78 & ᄀ & 12.85 & o & 25.76 & t & 29.18 \\
\hline 2 & \urcorner & 12.59 & ᄅ & 11.86 & ᄅ & 22.98 & 1 & 16.81 \\
\hline 3 & ᄂ & 9.48 & 人 & 9.07 & ᄂ & 17.68 & 1 & 16.55 \\
\hline 4 & 口 & 9.34 & z & 8.89 & 口 & 12.88 & $\perp$ & 12.37 \\
\hline 5 & o & 6.76 & व & 8.09 & \urcorner & 11.87 & $H / N$ & 9.58 \\
\hline
\end{tabular}

K M-B CDI=Korean version of MacArthur-Bates Communicative Development Inventories (Pae \& Kwak, 2011).

Table 5. Total ratio (\%) of consonants by place of articulation

\begin{tabular}{lccccc}
\hline & Bilabial & Alveolar & Palatal & Velar & Glottal \\
\hline Infant $(8-17 \mathrm{mo})$ & 22.86 & 37.48 & 9.80 & 27.37 & 2.49 \\
Toddler $(18-36 \mathrm{mo})$ & 19.35 & 42.74 & 10.40 & 24.12 & 3.38 \\
\hline
\end{tabular}

Table 6. Total ratio (\%) of consonants by manner of articulation

\begin{tabular}{lccccc}
\hline & Stops & Affricates & Fricatives & Nasals & Liquids \\
\hline Infant $(8-17 \mathrm{mo})$ & 40.12 & 9.80 & 10.42 & 28.77 & 10.89 \\
Toddler $(18-36 \mathrm{mo})$ & 37.44 & 10.40 & 11.80 & 25.58 & 14.78 \\
\hline
\end{tabular}

성 자음은 18 개 모두가 출현하였으며 고빈도 초성 자음 5 개는 $/ \neg /$, /ㄹ/, /ㅅ/, /ㅈ/, /ㅁ/였다. 종성 자음 7 개 중 고빈도 자음은 / O/, /ㄹ/, / ᄂ/, / ㅁ/,/ / / 순으로 나타났다. 단모음 7개 중 빈번하게 출현한 것 은/ / / , / / /,///였다.

K M-B CDI 영아용과 유아용 기록지에 나타난 어휘의 전체 자 음을 조음 위치별, 조음 방법별로 분석하여 Tables 5 와 6에 제시하 였다. 조음 위치별 자음 산출 비율은 영아용과 유아용 모두 치조음, 연구개음, 양순음, 경구개음, 성문음 순으로 나타났다. 조음 방법별 자음 산출 비율도 영아용과 유아용이 동일하게 파열음, 비음, 유음, 마찰음, 파찰음 순으로 나타났다.

\section{$\mathrm{KM}$-B CDI 어휘의 첫 말소리 비율}

K M-B CDI 영아용과 유아용 기록지에 나타난 단어의 첫 말소리 비율을 장애음, 공명자음, 모음으로 분류하여 Table 7에 제시하였 다. K M-B CDI 영아용과 유아용 모두 장애음으로 시작하는 단어 가 가장 많았으며, 장애음 중에서도 파열음이 높은 비율을 차지하 였다. 그 다음으로 모음으로 시작하는 단어와 공명자음 중 비음으 로 시작하는 단어 순으로 나타났다.
Table 7. Percentage of words beginning with obstruents, sonorants and vowels

\begin{tabular}{lcc}
\hline & Infant (8-17 mo) & Toddler (18-36 mo) \\
\hline Obstruents & 63.99 & 67.26 \\
Stops & 41.61 & 41.25 \\
Affricates & 9.79 & 11.24 \\
Fricatives & 12.59 & 14.77 \\
Sonorants & 14.69 & 14.77 \\
Nasals & 14.34 & 14.29 \\
Liquids & .35 & .48 \\
Vowels & 21.33 & 17.98 \\
\hline
\end{tabular}

Table 8. Total mean ratio (\%) by word structure

\begin{tabular}{|c|c|c|c|c|}
\hline \multirow{2}{*}{ Rank } & \multicolumn{2}{|l|}{ Infant (8-17 mo) } & \multicolumn{2}{|c|}{ Toddler (18-36 mo) } \\
\hline & Type & $\%$ & Type & $\%$ \\
\hline 1 & CVCV & 17.13 & CVCV & 15.89 \\
\hline 2 & CVC & 14.69 & CVC & 9.15 \\
\hline 3 & CV & 9.44 & CVCCV & 6.74 \\
\hline 4 & VCV & 4.90 & CV & 6.26 \\
\hline 5 & CVCCV & 4.20 & CVCVC & 5.94 \\
\hline 6 & CVCVC, CVCVCV & 3.85 & CVCVCV & 5.78 \\
\hline 7 & CVCCVC, VCCV & 3.15 & CVCCVC & 3.69 \\
\hline 8 & CGV, CVGV, CVCCVCV & 2.10 & VCV & 3.69 \\
\hline 9 & CVCGV, GVCV, CVCVGV & 1.74 & CVCCVCV & 2.89 \\
\hline 10 & VC, VCVC, CGVC, CVCVCCV, VCVCV & 1.40 & CVGV & 2.73 \\
\hline
\end{tabular}

\section{$\mathrm{KM}-\mathrm{B} \mathrm{CDI}$ 어휘의 낱말 구조}

$\mathrm{KM}$-B CDI 영아용과 유아용 기록지에 나타난 어휘의 낱말 구조 를 살펴본 뒤 상위 10 위까지 Table 8 에 제시하였다. 영아용 낱말 구 조 유형의 상위 5 개는 $\mathrm{CVCV}, \mathrm{CVC}, \mathrm{CV}, \mathrm{VCV}, \mathrm{CVCCV}$ 순으로 나타 났다. 유아용 낱말 구조 유형 상위 5 개는 CVCV, CVC, CVCCV, $\mathrm{CV}, \mathrm{CVCVC}$ 로 나타났다.

\section{2-30개월 한국 아동의 고빈도 표현 어휘의 음운 특성}

월령 집단별 과반수 이상 아동에게서 나타난 어휘의 음운 특성 을 살펴보았다. 각 월령 집단 대상자의 $75 \%$ 와 $50 \%$ 이상 공통적으 로 나타난 낱말에 대해 각각 음운 특성을 살펴보았다. 월령 집단별 과반수 이상 아동에게서 보고된 어휘와 비율은 Appendix 3에 제 시하였다.

\section{2-30개월 아동의 말소리 출현 빈도}

월령 집단별 $75 \%$ 이상과 $50 \%$ 이상 아동에게서 보고된 낱말에 나타난 상위 5 개 자음, 모음을 Table 9에 제시하였다. $75 \%$ 이상 아 동에게서 공통적으로 보고된 단어 수는 12-17개월 아동이 1개(예: 
Table 9. Percentage of phonemes of words

\begin{tabular}{|c|c|c|c|c|c|c|c|c|c|c|c|c|c|}
\hline & \multirow{3}{*}{ Rank } & \multicolumn{4}{|c|}{$12-17 \mathrm{mo}$} & \multicolumn{4}{|c|}{$18-23 \mathrm{mo}$} & \multicolumn{4}{|c|}{$24-30 \mathrm{mo}$} \\
\hline & & \multicolumn{2}{|c|}{$75 \%^{a}$} & \multicolumn{2}{|c|}{$50 \%^{b}$} & \multicolumn{2}{|l|}{$75 \%^{a}$} & \multicolumn{2}{|c|}{$50 \%^{b}$} & \multicolumn{2}{|c|}{$75 \%^{a}$} & \multicolumn{2}{|c|}{$50 \%^{b}$} \\
\hline & & Type & $\%$ & Type & $\%$ & Type & $\%$ & Type & $\%$ & Type & $\%$ & Type & $\%$ \\
\hline \multicolumn{14}{|l|}{ Consonants } \\
\hline \multirow[t]{5}{*}{ Initial } & 1 & $\square$ & 100 & 口 & 75 & ㅁ, ר & 25.00 & \urcorner$, \square,\llcorner$ & 12.50 & \urcorner & 15.84 & \urcorner & 13.41 \\
\hline & 2 & & & $\uplus$ & 25 & แ⿰ 一, ス, ᄂ & 12.50 & षи, 77 & 10.71 & 口 & 9.95 & ᄅ & 11.03 \\
\hline & 3 & & & & & & & $\forall, z$ & 7.14 & $\forall, \curlywedge, z$ & 7.69 & $\square$ & 8.66 \\
\hline & 4 & & & & & & & 人, ᄎ, $\overline{0}$ & 5.36 & $\llcorner$, ᄅ & 7.24 & $\forall$ & 8.10 \\
\hline & 5 & & & & & & & $ᄃ, \llbracket$ & 3.57 & רר & 6.79 & ᄉ & 7.82 \\
\hline \multirow[t]{5}{*}{ Final } & 1 & 口 & 100 & 口 & 100 & $\square, 0$, ᄅ & 33.33 & $\circ$ & 41.935 & ० & 31.00 & $\circ$ & 26.04 \\
\hline & 2 & & & & & & & ᄅ & 22.581 & 2 & 22.00 & ᄅ & 22.64 \\
\hline & 3 & & & & & & & ᄂ & 16.129 & \urcorner & 15.00 & \llcorner & 15.47 \\
\hline & 4 & & & & & & & व & 12.903 & ᄂ & 12.00 & ᄀ & 13.96 \\
\hline & 5 & & & & & & & \urcorner & 6.4516 & 口 & 11.00 & 口 & 12.83 \\
\hline \multirow[t]{5}{*}{ Vowel } & 1 & t. $t$ & 50 & t & 83.33 & t & 54.55 & r & 47.62 & t & 26.20 & r & 26.45 \\
\hline & 2 & & & 1 & 16.67 & $-1, n, T,-, \mid$ & 9.09 & I & 15.87 & I & 19.93 & I & 15.58 \\
\hline & 3 & & & & & & & $\perp$ & 11.11 & $\perp$ & 13.65 & 1 & 13.46 \\
\hline & 4 & & & & & & & 1 & 9.52 & t & 10.33 & $\perp$ & 12.16 \\
\hline & 5 & & & & & & & $T,-$ & 7.94 & H/H & 8.49 & $\top$ & 8.03 \\
\hline Number of word & & & & & 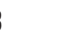 & 7 & & & & & & & 12 \\
\hline
\end{tabular}

${ }^{a}$ More than $75 \%$ of children, ${ }^{b}$ more than $50 \%$ of children.

엄마), 18-23개월 아동이 7개, 24-30개월 아동이 139개로 나타났다. $50 \%$ 이상 아동에게서 공통적으로 보고된 단어 수는 12-17개월 아 동이 3개(예: 엄마, 아빠, 맘마), 18-23개월 아동이 42개, 24-30개월 아동이 412 개로 나타났다.

$75 \%$ 이상 아동에게서 공통적으로 보고된 초성 자음은 $12-17$ 개 월에 양순음/ㅁ/, 18-23개월에 /ㅁ, ㄲ/,/빠, ᄀ, ㅈ, ㄴ/, 24-30개월에 /ᄀᄀ/,/ㅁ/,/ㅂ, ㅅ, ㅈ/,/ㄴ, ㄹ/ 순으로 나타났다. 즉, 조음 위치 면에 서 양순음만이 들어간 어휘를 표현하다가 아동이 월령이 증가하면 서 치조음, 경구개음, 연구개음이 모두 들어간 어휘를 표현하였다. 조음 방법 측면에서도 파열음, 비음만으로 구성된 어휘를 표현하던 아동이 점차 파찰음, 마찰음, 유음이 들어간 어휘를 표현하였다. 종 성 자음은 12-17개월에 양순음/ㅁ/, 18-23개월에 /ㅁ, O, ㄹ/, 24-30 개월에 /O/, / ㄹ/,/ ᄀ/, / ᄂ/, / ㅁ/ 순으로 나타나 점차 다양한 종성을 산출하는 것으로 나타났다. 단모음은 12-17개월에 / / , -1/, 18-23개

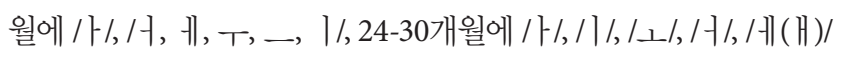
순이었다.

$50 \%$ 이상 아동에게서 공통적으로 보고된 초성 자음은 $12-17$ 개

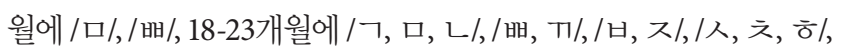
/ᄃ, ㄸ/,24-30개월에 / ᄀᄀ/,/ㄹ/,/ㅁ/,/ㅂ/,/ㅅ/ 순으로 나타났다. 조음 위치 면에서 양순음만 포함된 어휘를 사용하던 아동이 월령이 증 가하면서 치조음, 경구개음, 연구개음, 성문음이 모두 들어간 어휘
Table 10. Percentage of initial sounds of words

\begin{tabular}{|c|c|c|c|c|c|c|}
\hline & \multicolumn{2}{|c|}{$12-17 \mathrm{mo}$} & \multicolumn{2}{|c|}{$18-23 \mathrm{mo}$} & \multicolumn{2}{|c|}{$24-30 \mathrm{mo}$} \\
\hline & $75 \%{ }^{\mathrm{a}}$ & $50 \%^{b}$ & $75 \%$ & $50 \%$ & $75 \%$ & $50 \%$ \\
\hline Number of words & 1 & 3 & 7 & 42 & 139 & 412 \\
\hline Obstruents & .00 & .00 & 28.57 & 54.76 & 62.59 & 67.47 \\
\hline Stops & .00 & .00 & 28.57 & 35.71 & 41.01 & 43.20 \\
\hline Affricates & .00 & .00 & .00 & 7.14 & 10.07 & 10.92 \\
\hline Fricatives & .00 & .00 & .00 & 11.90 & 11.51 & 13.59 \\
\hline Sonorants & .00 & 33.33 & 28.57 & 9.52 & 12.95 & 13.60 \\
\hline Nasals & .00 & 33.33 & 28.57 & 9.52 & 12.95 & 13.11 \\
\hline Liquids & .00 & .00 & .00 & .00 & .00 & .24 \\
\hline Vowels & 100 & 66.67 & 42.86 & 35.71 & 24.46 & 18.93 \\
\hline
\end{tabular}

a More than $75 \%$ of children, ${ }^{b}$ more than $50 \%$ of children.

를 표현하였다. 조음 방법 측면에서도 파열음, 비음만으로 이루어 진 어휘를 표현하던 아동이 점차 파찰음, 마찰음, 유음이 모두 포함 된 어휘를 표현하였다. 종성 자음은 12-17개월에 양순음/ㅁ/, 18-23 개월에 /O/, /ㄹ/,/L/, /ㅁ/,/ᄀᄀ/, 24-30개월에 /O/,/2ᄅ/,/L/,/ᄀ/,/ㅁ/ 순이었다. 단모음은 12-17개월에 / / /,/ / /, 18-23개월에 / / /,///,/工_/,

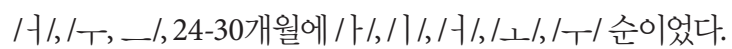

\section{2-30개월 아동의 첫 말소리 유형 비율}

월령 집단별 $75 \%$ 이상 아동과 $50 \%$ 이상 아동에게서 보고된 낱 
Table 11. Percentage of word structure

\begin{tabular}{|c|c|c|c|c|c|c|c|c|c|c|c|c|}
\hline \multirow{3}{*}{ Rank } & \multicolumn{4}{|c|}{$12-17 \mathrm{mo}$} & \multicolumn{4}{|c|}{$18-23 \mathrm{mo}$} & \multicolumn{4}{|c|}{$24-30 \mathrm{mo}$} \\
\hline & \multicolumn{2}{|c|}{$75 \%^{a}$} & \multicolumn{2}{|c|}{$50 \%^{b}$} & \multicolumn{2}{|l|}{$75 \%$} & \multicolumn{2}{|c|}{$50 \%$} & \multicolumn{2}{|c|}{$75 \%$} & \multicolumn{2}{|c|}{$50 \%$} \\
\hline & Type & $\%$ & Type & $\%$ & Type & $\%$ & Type & $\%$ & Type & $\%$ & Type & $\%$ \\
\hline 1 & VCV & 100 & VCV & 66.67 & VCV & 33.33 & VCV, CVC & 16.28 & CVCV & 15.29 & CVCV & 17.87 \\
\hline 2 & - & - & CVCV & 33.33 & $\begin{array}{c}\text { CV, CVC, VC, CVCV, } \\
\text { CGVCV, CVCCVC, }\end{array}$ & 11.11 & CV & 11.63 & CVC & 14.12 & CVC & 11.47 \\
\hline 3 & - & - & - & - & - & - & CVCCVC & 9.30 & CV & 10.00 & CV & 6.93 \\
\hline 4 & - & - & - & - & & - & CVCV & 6.98 & VCV & 7.06 & VCV & 6.40 \\
\hline 5 & - & - & - & & - & - & CGVCV, VCCV & 4.65 & CVCVC & 5.29 & & \\
\hline
\end{tabular}

a More than $75 \%$ of children, ${ }^{\mathrm{b} m o r e}$ than $50 \%$ of children.

말에 나타난 첫 말소리 유형 비율을 Table 10 에 제시하였다. $75 \%$ 이 상아동에게서 공통적으로 보고된 낱말을 살펴보았을 때, 장애음으 로 시작하는 낱말은 12-17개월 아동에게서 나타나지 않다가 18-23 개월 아동이 약 $29 \%, 24-30$ 개월 아동이 약 $63 \%$ 로 나타났다. 공명 자음으로 시작하는 낱말은 12-17개월에 나타나지 않다가 18-23개 월 아동이 약 $29 \%, 24-30$ 개월 아동이 약 $13 \%$ 로 나타났다. 모음으 로 시작하는 낱말 비율은 $12-17$ 개월 아동이 $100 \%, 18$-23개월 아동 이 약 $43 \%, 24-30$ 개월 아동이 약 $25 \%$ 로 나타났다. 즉 월령이 증가 할수록 장애음으로 시작하는 낱말 비율은 증가하고 모음으로 시 작하는 낱말 비율은 감소하는 추이를 보였다.

$50 \%$ 이상 아동에게서 공통적으로 보고된 낱말을 살펴보았을 때, 장애음으로 시작하는 낱말은 12-17개월 아동에게서 나타나지 않다가 $18-23$ 개월 아동이 약 $55 \%, 24-30$ 개월 아동이 약 $67 \%$ 로 나 타났다. 공명자음으로 시작하는 낱말은 $12-17$ 개월에 약 $33 \%, 18-23$ 개월에 약 $10 \%, 24-30$ 개월 아동이 약 $14 \%$ 로 나타났다. 모음으로 시 작하는 낱말 비율은 $12-17$ 개월 아동이 약 $67 \%, 18$-23개월 아동이 약 36\%, 24-30개월 아동이 약 $19 \%$ 로 나타났다. 즉 월령이 증가할 수록 모음으로 시작하는 낱말 비율이 감소하였음을 알 수 있다. $50 \%$ 이상 아동에게서 공통적으로 보고된 낱말의 첫 말소리 유형 은 월령이 증가할수록 장애음 비율이 증가하고 모음으로 시작하는 낱말 비율은 감소하는 경향을 보였다.

\section{2-30개월 아동의 낱말 구조}

$12-30$ 개월 아동의 과반수 이상에서 보고된 단어를 $75 \%$ 이상 아 동에게서 보고된 단어, $50 \%$ 이상 아동에게서 보고된 단어로 나누 어 살펴보았다. 나타난 낱말 구조 중 상위 5 개 낱말 구조의 유형과 비율을 Table 11에 제시하였다. $75 \%$ 이상 아동에게서 공통적으로 보고된 낱말에서 12-17개월 아동은 2음절 VCV 낱말 구조만을 산 출하였다. $18-23$ 개월 아동의 낱말 구조는 1음절 3 개, 2 음절 4 개로
총 7개 유형이었다. 이 중 가장 많이 나타난 낱말 구조는 VCV였다. 24-30개월 아동의 낱말 구조는 1 음절 8 개, 2 음절 24 개, 3 음절 13 개, 4 음절 5 개, 5 음절 1 개로 총 51 개 유형이 출현하였다. 이 중 상위 5 개 낱말 구조는 $\mathrm{CVCV}, \mathrm{CVC}, \mathrm{CV}, \mathrm{VCV}, \mathrm{CVCVC}$ 로 주로 1, 2음절 단 어를 산출함을 알수 있었다.

$50 \%$ 이상 아동에게서 보고된 단어에서 12-17개월 아동은 2음절 $\mathrm{VCV}, \mathrm{CVCV}$ 낱말 구조만을 산출하였다. 18-23개월 아동의 낱말 구조는 1 음절 4 개, 2 음절 11 개, 3 음절 3 개, 4 음절 2 개로 총 20 개 유 형이었다. 이 중 상위 5 개 낱말 구조는 $\mathrm{CVC}, \mathrm{VCV}, \mathrm{CV}, \mathrm{CVCCVC}$, CVCV, CGVCV, VCCV 순으로 나타났다. 24-30개월 아동의 낱말 구조는 1 음절 8 개, 2 음절 27 개, 3 음절 24 개, 4 음절 12 개, 5 음절 1 개 로 총 72 개 유형이 출현하였다. 이 중 상위 5 개 낱말 구조는 $\mathrm{CVCV}$, $\mathrm{CVC}, \mathrm{CV}, \mathrm{VCV}, \mathrm{CVCVC}$ 로 24-30개월 아동은 주로 1, 2음절 단어 를 산출하였다.

\section{논의 및 결론}

본 연구는 음운과 어휘의 양방향적인 상호관계가 활발하게 관찰 되는 12 개월에서 30 개월 한국 아동의 표현 어휘상에 나타난 음운 특징을 살펴보고자 하였다. 먼저 한국 아동 어휘에 대한 기본적인 특성을 살펴보고자, 해당 시기에 검사도구로 보편적으로 사용되는 어휘 체크리스트인 K M-B CDI 영아용, 유아용에 포함된 어휘 목 록의 음운 특성을 분석하였다. 또한 언어발달 수준에 따라 어휘와 음운 특성을 자세히 살펴보기 위해 일반아동을 12-17개월, 18-23 개월, 24-30개월의 월령 집단으로 나누어 해당 집단의 $50 \%$ 와 $75 \%$ 아동이 표현한다고 보고된 어휘를 토대로 말소리 출현 빈도와 낱 말의 첫소리 유형 및 낱말 구조를 살펴보았다.

먼저 8-17개월의 아동에게 실시되는 K M-B CDI 영아용에 수록 된 전체 286 개 낱말 중에서 2음절어가 전체 어휘 중 $52.10 \%$ 를 차지 
하면서 가장 많았으며, 그 다음은 1 음절어(30.42\%)가 많았다. KM-B $\mathrm{CDI}$ 유아용의 경우도 623 개 낱말 중 2음절어(55.22\%)가 가장 많았 으며, 3음절어(20.71\%)가 그 다음으로 많았다. K M-B CDI에 수록 된 어휘의 말소리를 살펴본 결과, K M-B CDI 영아용 어휘에서는 자음 빈도가 / ᄀ//,/2/, / ㄴ/,/ㅁ/, /ㅂ/ 순으로 나타났다. 모음 빈도는 / / / / / / /, / ㄷ/ 순으로 나타났다. K M-B CDI 유아용에서는 자음은 /ㄹ/,/ ᄀ//, / ㄴ/, /ㅁ/,/O/ 순으로 나타났다. 모음은/F/,///,/// 순으 로 나타났다. 조음 위치별 자음 비율은 영아용과 유아용 모두 치조 음, 연구개음, 양순음, 경구개음, 성문음 순으로 나타났다. 조음 방 법별 자음 비율도 영아용과 유아용이 동일하게 파열음, 비음, 유음, 마찰음, 파찰음 순으로 나타났다. K M-B CDI 영아용과 유아용 기 록지에 나타난 단어의 첫 말소리 비율을 살펴본 결과 $\mathrm{K} \mathrm{M-B} \mathrm{CDI}$ 영아용과 유아용 어휘의 약 64-67\%가 장애음으로 시작하였으며 나머지는 모음 또는 공명자음으로 시작하였다. 세부적으로는 파열 음이 가장 높았으며, 다음으로 모음과 비음의 순으로 비율이 높았 다. 낱말 구조는 영아용, 유아용 모두 CVCV, CVC 가 가장 높은 빈 도를 차지하였으며, 이 후 $\mathrm{KM}-\mathrm{B} \mathrm{CDI}$ 영아용은 $\mathrm{CV}, \mathrm{VCV}, \mathrm{CVCCV}$ 순으로, 유아용은 CVCCV, CV, CVCVC 순으로 높았다. 이러한 K $\mathrm{M}-\mathrm{B} \mathrm{CDI}$ 에 수록된 어휘의 음운 특성은 한국어 초기 어휘에 대한 목표 형태에 대한 일반적인 음운 정보를 제시한다.

$12-30$ 개월 아동의 부모에게 K M-B CDI 를 실시한 결과를 토대 로 월령 집단별로 $50 \%-75 \%$ 의 아동이 습득한 표현 어휘와 음운 특 성을 살펴보았다. $75 \%$ 이상 아동에게서 표현한다고 공통적으로 보 고된 단어 수는 12-17개월 아동이 1개, 18-23개월 아동이 7개, 24-30 개월 아동이 139 개로 나타났다. $50 \%$ 이상 아동에게서 공통적으로 보고된 단어 수는 12-17개월 아동이 3개, 18-23개월 아동이 42개, 24-30개월 아동이 412개로 나타났다. 18-23개월에 대다수의 아동 이 50 개 미만의 표현 어휘를 보이다 24 개월 이후에 비약적으로 표 현 어휘수가 증가하는 것이 관찰되었다. 한국 아동의 이러한 어휘 습득 수준은 미국 영어를 습득하는 아동이 2세경에 일반적으로 300 개의 어휘를 습득한다는 규준과 비슷하다(Fenson, Marchman, Thal, Dale, Reznick, \& Bates, 2007). 12-17개월에 75\% 이상의 아동 은 양순음/미이 포함된 어휘만을 표현하다가, 표현 어휘가 증가하 면서 18-23개월에는/ㅃ, ᄂ, ᄀ, T, 지음소가 새롭게 자음 목록에 들어가면서 빈번하게 사용하였다. 24-30개월에는 / 시를 포함한 한 국어의 거의 모든 자음이 포함된 다향한 어휘를 구사하게 되었다. 모음의 경우에도 12-17개월에는 표현 어휘 수가 적어 어휘에 / / /, / 기만 모음목록에 포함되다가 18개월 이후에는 어휘수가 증가하 면서/ㄱ, , T, _, / / 등의 다양한 모음이 산출되었다.

$12-30$ 개월 아동의 초기 표현 어휘 목록에 나타난 첫 말소리 유형
비율도 살펴보았다. 만약 낱말이 아동의 음소 목록에 포함된 소리 로 시작할 경우 아동이 해당 낱말을 쉽게 산출하고 아동의 심상어 휘집(lexicon)에 빠르게 포함되기 때문에(Ferguson \& Farwell, 1975; Leonard, Schwartz, Morris, \& Chapman, 1981; Schwartz \& Leonard, 1982; Schwartz, Leonard, Loeb, \& Swanson, 1987), 낱말의 첫 소리를 살펴보는 것은 아동의 음운과 어휘 습득 수준과 특성을 이 해하는 데 중요하다. 12-17개월 아동은 모두 모음 또는 비음으로만 시작하는 낱말만 표현하다가 18 개월 이후에는 점진적으로 파열음 으로 시작하는 낱말이 증가하다가 24-30개월에는 $75 \%$ 이상의 아 동이 표현하는 낱말 중 $63 \%$ 가 장애음으로 시작하는 것으로 나타 났다. 반면에 모음으로 시작하는 낱말 비율은 12-17개월 아동이 $100 \%, 18-23$ 개월 아동이 약 $43 \%, 24-30$ 개월 아동이 약 $25 \%$ 로 나타 나 월령이 증가할수록 모음으로 시작하는 낱말 비율이 감소하였 다. 12-30개월 아동의 초기 표현 어휘 목록에 나타난 낱말 구조도 살펴보았다. $12-17$ 개월에는 75\% 이상 아동에게서 공통적으로 보 고된 낱말의 구조는 모두 2음절 $\mathrm{VCV}$ 뿐이었으며, 표현 어휘수가 증 가한 18-24개월에도 VCV가 가장 높은 비율을 차지하였다. 이 후 24-30개월에서는 낱말 구조가 다양해지면서 CVCV, CVC, CV, $\mathrm{VCV}, \mathrm{CVCVC}$ 순으로 빈번하게 사용되었다. $12-24$ 개월에 $75 \%$ 이 상의 아동이 표현하는 낱말의 구조에서 $\mathrm{VCV}$ 가 높은 것은 한국어 초기 어휘의 독특한 특성이라고 할 수 있다. 52 명 미국 아동의 첫 10 개의 낱말을 분석한 Bernhardt와 Stoel-Gammon (1996)은 아동의 $90 \%$ 가 CVCV 낱말(예: mommy, daddy, byebye)을 산출했다고 보 고하였다. 이러한 미국 아동을 포함한 영어권 아동의 첫 낱말의 우 세한 음절 구조는 초기 발성에서부터 나타나는데 아동의 생후 6개 월 이후 초기 발성에는 $/ \mathrm{m}, \mathrm{b}, \mathrm{d} /$ 음소가 포함된 $\mathrm{CV}$ 또는 $\mathrm{CVCV}$ 구 조가 우세하다(Stoel-Gammon, 1991, 2011). 반면에 한국 아동은 6 개월 이후 초기 발성에 모음으로 시작하는 VCV 구조가 높은 비율 로 산출된다(Ha, Seol, \& Pae, 2014; Ha, Oller, \& Johnson, 2018). $\mathrm{VCV}$ 구조는 18-23개월 이전 표현 어휘가 본격적으로 증가되기 이 전까지 초기 낱말의 기본 구조로 빈번하게 사용된다. 특히 초기 발 성에부터 나타나는 두 언어 간 음절 구조의 차이는 최근 $\mathrm{Ha}$ 등 (2018)에 잘 나타났다. 한국어와 영어를 단일 모국어로 습득하는 아동의 발성을 암맹분석(blind analysis)한 결과, 두 언어권 아동 모 두에게 공통적으로 $\mathrm{VCV}, \mathrm{CV}, \mathrm{CVCV}$ 가 가장 높은 비율로 산출되 었다. 하지만 상대적으로 우세한 발성 구조는 언어 간 차이를 보였 는데 한국 아동은 VCV 구조가 가장 우세해 영어권 아동에 비해 산출 비율이 유의미하게 높았다. 반면에 영어권 아동은 $\mathrm{CV}$ 가 가장 높은 비율로 산출되었다. 초기 발성 또는 어휘의 특성을 살펴본 선 행연구와 본 연구의 결과는 초기 발성의 음소와 구조가 초기 낱말 
의 음운 패턴의 밑바탕이 된다는 가정을 지지하고 있다(Stoel-Gammon, 2011). 흥미로운 점은 10 개 정도의 표현 어휘를 습득할 때 보 이던 VCV 구조가 우세한 특징은 이후 표현 어휘가 증가하면서 차 츰 감소해 영어권 아동과 비슷해진다. 미국 아동이 습득한 첫 100 낱말의 음운 특성을 살펴보면 낱말의 $57 \%$ 가 파열음으로 시작하 고, CVCV와 CVC의 비율이 높다(Stoel-Gammon, 1998). 마찬가지 로 본 연구에서 한국 아동의 경우 100 개 이상의 표현 어휘를 산출 하게 되는 24 개월 이후에는 영어권 아동과 비슷하게 파열음으로 시작하는 CVCV가 가장 높은 비율을 차지하였다.

본 연구는 한국 아동의 기본적인 어휘 특성을 전체적으로 살펴 보고자 K M-B CDI에 포함된 어휘와 12-30개월 아동의 보호자가 산출한다고 보고한 어휘의 음운 특성을 분석하였다. KM-B CDI에 포함된 영아용, 유아용 어휘의 음운 특성을 분석한 결과와 부모에 의해 실제 12-30개월 아동이 표현한다고 보고된 어휘의 음운 특성 은 연령 집단별 차이가 있었다. 12-17개월에는 대다수의 아동들이 /빠, 미만을 VCV 구조에서 산출하다가 18 개월 이후에는 표현 어 휘수가 점진적으로 증가하면서 다양한 파열음과 비음을 산출하고 점진적으로 파찰음, 마찰음이 첨가되었다. 또한 $\mathrm{VCV}$ 구조의 낱말 비율이 여전히 높지만 첫소리에 장애음이나 비음이 산출되면서 $\mathrm{CV}, \mathrm{CVC}, \mathrm{CVCV}$ 의 낱말 구조가 포함되면서 다양해졌다. 24 개월 이후에는 평균 357 개의 표현 어휘수를 보이면서 아동이 빈번하게 산출하는 자음과 낱말 구조의 유형이 검사도구의 전체적인 음운 특성과 유사해졌다. 이러한 월령집단별 음운상의 변화는 18-30개 월 아동의 자발화를 토대로 음운 특성을 분석한 $\mathrm{Ha}$ 와 $\mathrm{Pi}$ (2016)의 연구결과와 일관성이 있다. $\mathrm{Ha}$ 와 $\mathrm{Pi}$ (2016)의 연구에서는 모음으로 시작하는 어절의 비율이 18-24개월 아동의 자발화에서는 가장 높 았으나 25-30개월 아동의 자발화에서는 모음으로 시작하는 어절 의 비율은 감소하고 비음이나 장애음으로 시작하는 어절의 비율이 증가하였다.

본 연구에서 살펴본 $\mathrm{K} \mathrm{M-B} \mathrm{CDI는} \mathrm{아동의} \mathrm{말운동학적} \mathrm{발달} \mathrm{수}$ 준에 근거하기보다는 아동에게 의미적, 인지적, 화용적으로 친숙하 고 유용한 어휘의 총 목록이라고 할 수 있다. 따라서 18 개월 이전에 는 말운동학적 또는 음운 발달상의 제약에 따라 제한적인 어휘만 을 산출하다가 점차 음소 목록과 음절 구조가 다양해지면서 어휘 목록도 확장되어 아동은 검사도구의 전체 어휘의 음운 특성과 유 사한 음운 특성을 보이게 된다. 이러한 결과는 언어발달 초기에 어 휘와 음운이 서로 긴밀한 영향을 주고 받으면서 발달해 가는 모습 을 반영한다고 할 수 있다.

그리고 본 연구는 아동의 실제로 발음한 형태가 아닌 성인의 목 표 형태에 대한 음운 분석이다. 어휘 체크리스트의 속성상 아동 발
음의 정확성 여부보다는 아동이 의도한 바를 부모가 이해한 어휘 목록에 대한 음운 분석이다. 즉 본 연구는 아동의 실제 음운 특성 이라기보다는 궁극적으로 아동들이 발달해 나아가야 하는 목표 음운 특성이라고 할 수 있다. 또한 의미적으로 아동에게 친숙하고 유용한 어휘 목록에 대한 분석이다. 따라서 본 연구결과는 어휘와 음운 영역에서 느리거나 비정상적인 발달을 보이는 아동의 언어 중 재를 계획할 때 두 영역의 발달을 동시에 촉진하기 위한 목표 어휘 를 선정하는 데 참조자료로 활용될 수 있겠다. 한국 아동에게 기능 적이고 의미적으로 친숙한 어휘인 동시에 음운 빈도와 습득 순서, 첫소리 유형, 낱말 구조의 발달 특성을 동시에 고려하여 목표 어휘 를 선정하는 것이 필요하겠다.

\section{REFERENCES}

Bernhardt, B., \& Stoel-Gammon, C. (1996). Underspecification and markedness in normal and disordered phonological development. Children's Language, 9, 33-54.

Chapman, K. L., Hardin-Jones, M., \& Halter, K. A. (2003). The relationship between early speech and later speech and language performance for children with cleft lip and palate. Clinical Linguistics \& Phonetics, 17, 173-197.

Choi, M. S., Kim, S. J., \& Kim, H. S. (2014). Lexical and phonology development in 2-year-old Korean children. Korean Journal of Early Childhood Special Education, 14, 133-152.

Estrem, T., \& Broen, P. A. (1989). Early speech production of children with cleft palate. Journal of Speech, Language, and Hearing Research, 32, 12-23.

Fenson, L., Dale, P., Reznick, J., Thal, D., Bates, E., Hartung, J., ... \& Reilly, J. (1993). MacArthur Communicative Development Inventories: User's Guide and Technical Manual. Baltimore, MD: Paul H. Brookes Publishing Co.

Fenson, L., Marchman, V. A., Thal, D. J., Dale, P. S., Reznick, J. S., \& Bates, E. (2007). MacArthur-Bates Communicative Development Inventories: User's Guide and Technical Manual. Baltimore, MD: Paul H. Brookes Publishing Co.

Ferguson, C. A., \& Farwell, C. B. (1975). Words and sounds in early language acquisition. Language, 51, 419-439.

Ha, S., \& Pi, M. (2016). Consonant frequency and phonological characteristics of eojeols in spontaneous speech samples from 18-to 30-month-old Korean children. Communication Sciences \& Disorders, 21, 567-579.

Ha, S., Oller, K., \& Johnson, C. (2018). Cross-linguistic comparisons of babbling shapes in Korean- and English-learning infants. Paper presented at the International Child Phonology Conference, Crete, Greece. 
Ha, S., Seol, A., So, J., \& Pae, S. (2016). Speech and language development patterns of Korean two-year-old children from analysis of spontaneous utterances. Communication Sciences \& Disorders, 21, 47-59.

Ha, S., Seol, A., \& Pae, S. (2014). Vocal development of typically developing infants. Phonetics and Speech Sciences, 6, 161-169.

Jang, H. S., Seo, S. J., \& Ha, J. Y. (2008). Developmental assessment for the early intervention program planning. Seoul: Hakjisa.

Kim, Y. T., Kim, K. H., Yoon, H. R., \& Kim, H. S. (2003). Sequenced Language Scale for Infants (SELSI). Seoul: Special Education Publishing.

Leonard, L. B., Schwartz, R. G., Morris, B., \& Chapman, K. (1981). Factors influencing early lexical acquisition: lexical orientation and phonological composition. Child Development, 52, 882-887.

Oller, D. K., Wieman, L. A., Doyle, W. J., \& Ross, C. (1976). Infant babbling and speech. Journal of Child Language, 3, 1-11.

Pae, H., \& Kim, H. (2010). Study on the conceptual distribution of young children vocabulary based on the M-B CDI-K. Journal of Speech \& Hearing Disorders, 19, 89-107.

Pae, S. (1993). Early vocabulary in Korean: are nouns easier to learn than verbs? (Doctoral dissertation). University of Kansas, Lawrence, KS.

Pae, S. Y., Kwak, K. J., Kim, K. Y., Jung, K. H., \& Kim, H. J. (2009). Supporting the language development of children from multicultural families: a survey of mothers and developmental supporters. Journal of Speech \& Hearing Disorders, 18, 165-184.

Pae, S., \& Kwak, K. C. (2011). Korean MacArthur-Bates Communicative Development Inventories (KM-B CDI). Seoul: Mindpress.

Park, H. J., \& Pae, S. (2003). Early expressive vocabulary development of Korean children with hearing impairment. Korean Journal of Communication \& Disorders, 8, 66-81.
Paul, R., \& Jennings, P. (1992). Phonological behavior in toddlers with slow expressive language development. Journal of Speech, Language, and Hearing Research, 35, 99-107.

Pi, M., \& Ha, S. (2018). Relationships between phonological, lexical, and grammatical skills in 18-to 30-month-old korean children. Communication Sciences \& Disorders, 23, 1-10.

Rescorla, L., \& Ratner, N. B. (1996). Phonetic profiles of toddlers with specific expressive language impairment (SLI-E). Journal of Speech, Language, and Hearing Research, 39, 153-165.

Schwartz, R. G., \& Leonard, L. B. (1982). Do children pick and choose? An examination of phonological selection and avoidance in early lexical acquisition. Journal of Child Language, 9, 319-336.

Schwartz, R. G., Leonard, L. B., Loeb, D. M. F., \& Swanson, L. A. (1987). Attempted sounds are sometimes not: an expanded view of phonological selection and avoidance. Journal of Child Language, 14, 411-418.

Shin, J. Y., \& Lee, Y. (2008). The characteristics of expressive vocabulary of young children with autism spectrum disorder. Journal of the Korean Association for Persons with Autism, 8, 143-154.

Stoel-Gammon, C. (1991). Normal and disordered phonology in two-yearolds. Topics in Language Disorders, 11, 21-32.

Stoel-Gammon, C. (1998). Sounds and words in early language acquisition: the relationship between lexical and phonological development. In R. Paul (Ed.), Exploring the speech-language connection (pp. 25-52). Baltimore, MD: Paul H. Brookes Publishing Co.

Stoel-Gammon, C. (2011). Relationships between lexical and phonological development in young children. Journal of Child Language, 38, 1-34.

Yang, S. (2005). An acoustic and auditory study of Korean syllable final stops. Korean, 269, 77-100. 
Appendix 1. K M-B CDI 영아용에 나타난 말소리 비율

\begin{tabular}{|c|c|c|c|c|c|c|c|c|}
\hline \multirow{2}{*}{ 순위 } & \multicolumn{2}{|c|}{ 전체 자음 } & \multicolumn{2}{|c|}{ 초성 자음 } & \multicolumn{2}{|c|}{ 종성 자음 } & \multicolumn{2}{|c|}{ 단모음 } \\
\hline & 음소 & 비율(\%) & 음소 & 비율(\%) & 음소 & 비율(\%) & 음소 & 비율(\%) \\
\hline 1 & ᄀ & 14.00 & ᄀ & 14.10 & $\circ$ & 28.57 & t & 32.29 \\
\hline 2 & ᄅ & 10.89 & $\square$ & 10.47 & ᄅ & 21.14 & I & 19.50 \\
\hline 3 & ᄂ & 10.58 & $\forall$ & 10.47 & \llcorner & 17.71 & $\perp$ & 13.84 \\
\hline 4 & $\square$ & 10.42 & ᄉ & 8.97 & \urcorner & 13.71 & 1 & 13.63 \\
\hline 5 & $\forall$ & 8.86 & \llcorner & 7.91 & $\square$ & 10.29 & $T$ & 9.01 \\
\hline 6 & $\circ$ & 7.78 & x & 7.91 & ㅂ & 4.57 & $H / H$ & 8.18 \\
\hline 7 & ᄉ & 6.53 & e & 7.05 & ᄃ & 4.00 & - & 3.56 \\
\hline 8 & x & 5.75 & רา & 5.98 & & & & \\
\hline 9 & ᄃ & 4.67 & え & 5.56 & & & & \\
\hline 10 & 77 & 4.35 & ᄃ & 4.91 & & & & \\
\hline 11 & ᄎ & 4.04 & क & 3.42 & & & & \\
\hline 12 & के & 2.49 & 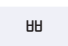 & 2.78 & & & & \\
\hline 13 & 世 & 2.02 & 匹 & 2.56 & & & & \\
\hline 14 & 匹 & 1.87 & E & 2.14 & & & & \\
\hline 15 & E & 1.56 & II & 2.14 & & & & \\
\hline 16 & II & 1.56 & 从ᄊ & 1.92 & & & & \\
\hline 17 & 从ᄊ & 1.40 & э & 1.71 & & & & \\
\hline 18 & 7 & 1.24 & & & & & & \\
\hline
\end{tabular}

Appendix 2. K M-B CDI 유아용에 나타난 말소리 비율

\begin{tabular}{|c|c|c|c|c|c|c|c|c|}
\hline \multirow{2}{*}{ 순위 } & \multicolumn{2}{|c|}{ 전체 자음 } & \multicolumn{2}{|c|}{ 초성 자음 } & \multicolumn{2}{|c|}{ 종성 자음 } & \multicolumn{2}{|c|}{ 단모음 } \\
\hline & 음소 & 비율(\%) & 음소 & 비율(\%) & 음소 & 비율(\%) & 음소 & 비율(\%) \\
\hline 1 & e & 14.78 & ᄀ & 12.85 & $\circ$ & 25.76 & r & 29.18 \\
\hline 2 & ᄀ & 12.59 & ᄅ & 11.86 & ᄅ & 22.98 & $t$ & 16.81 \\
\hline 3 & \llcorner & 9.48 & ᄉ & 9.07 & \llcorner & 17.68 & I & 16.55 \\
\hline 4 & $\square$ & 9.34 & x & 8.89 & $\square$ & 12.88 & $\perp$ & 12.37 \\
\hline 5 & $\circ$ & 6.76 & 口 & 8.09 & ᄀ & 11.87 & $H / N$ & 9.58 \\
\hline 6 & ᄉ & 6.69 & ㅂ & 7.37 & ᄃ & 4.55 & $\top$ & 9.32 \\
\hline 7 & $\forall$ & 6.56 & ᄃ & 6.74 & $\forall$ & 4.29 & - & 6.18 \\
\hline 8 & x & 6.56 & ᄂ & 6.56 & & & & \\
\hline 9 & ᄃ & 6.16 & क & 4.58 & & & & \\
\hline 10 & के & 3.38 & ᄎ & 4.49 & & & & \\
\hline 11 & ᄎ & 3.31 & רר & 4.04 & & & & \\
\hline 12 & רา & 2.98 & E & 2.96 & & & & \\
\hline 13 & E & 2.19 & II & 2.61 & & & & \\
\hline 14 & II & 1.92 & F & 2.43 & & & & \\
\hline 15 & $\exists$ & 1.79 & 匹ᄄ & 2.34 & & & & \\
\hline 16 & 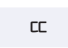 & 1.72 & 从 & 2.34 & & & & \\
\hline 17 & 从 & 1.72 & 빠 & 2.07 & & & & \\
\hline 18 & 世 & 1.52 & 双 & .72 & & & & \\
\hline 19 & 皮 & .53 & & & & & & \\
\hline
\end{tabular}


Appendix 3. 월령 집단별 $50 \%$ 이상 아동에게서 보고된 어휘

$1.12-17$ 개월 아동

\begin{tabular}{lllc}
\hline & & $N$ & $\%$ \\
\hline 1 & 엄마 & 68 & 76.40 \\
2 & 아빠 & 63 & 70.79 \\
3 & 맘마 & 60 & 67.42 \\
\hline
\end{tabular}

2. $18-23$ 개월 아동

\begin{tabular}{|c|c|c|c|}
\hline & & $\mathrm{N}$ & $\%$ \\
\hline 1 & 엄마 & 67 & 91.78 \\
\hline 2 & 아빠 & 65 & 89.04 \\
\hline 3 & 네 & 61 & 83.56 \\
\hline 4 & 물 & 59 & 80.82 \\
\hline 5 & 응 & 59 & 80.82 \\
\hline 6 & 과자 & 58 & 79.45 \\
\hline 7 & 까까 & 58 & 79.45 \\
\hline 8 & 멍멍 & 54 & 73.97 \\
\hline 9 & 아니 & 53 & 72.60 \\
\hline 10 & 빠이빠이 & 50 & 68.49 \\
\hline 11 & 얌얌 & 49 & 67.12 \\
\hline 12 & 야옹 & 47 & 64.38 \\
\hline 13 & 어흥 & 47 & 64.38 \\
\hline 14 & 음매 & 47 & 64.38 \\
\hline 15 & 공 & 47 & 64.38 \\
\hline 16 & 빵 & 47 & 64.38 \\
\hline 17 & 할아버지 & 47 & 64.38 \\
\hline 18 & 바나나 & 46 & 63.01 \\
\hline 19 & 빵빵 & 45 & 61.64 \\
\hline 20 & 차 & 45 & 61.64 \\
\hline 21 & 자동차 & 45 & 61.64 \\
\hline 22 & 할머니 & 45 & 61.64 \\
\hline 23 & 우유 & 43 & 58.90 \\
\hline 24 & 쉬 & 42 & 57.53 \\
\hline 25 & 안녕 & 42 & 57.53 \\
\hline 26 & 치즈 & 41 & 56.16 \\
\hline 27 & 눈 & 41 & 56.16 \\
\hline 28 & 꿀꿀 & 40 & 54.79 \\
\hline 29 & 코 & 40 & 54.79 \\
\hline 30 & 또 & 40 & 54.79 \\
\hline 31 & 아기 & 40 & 54.79 \\
\hline 32 & 아가 & 40 & 54.79 \\
\hline 33 & 귤 & 39 & 53.42 \\
\hline 34 & 응가 & 39 & 53.42 \\
\hline 35 & 똥 & 39 & 53.42 \\
\hline 36 & 발 & 38 & 52.05 \\
\hline 37 & 안돼 & 38 & 52.05 \\
\hline 38 & 꽥꽥 & 37 & 50.68 \\
\hline 39 & 신 & 37 & 50.68 \\
\hline 40 & 신발 & 37 & 50.68 \\
\hline 41 & 이모 & 37 & 50.68 \\
\hline 42 & 가 & 37 & 50.68 \\
\hline
\end{tabular}




\section{24-30개월 아동}

\begin{tabular}{|c|c|c|c|c|c|c|c|c|c|c|c|}
\hline & & $N$ & $\%$ & & & $N$ & $\%$ & & & $N$ & $\%$ \\
\hline 1 & 빵빵 & 30 & 96.77 & 126 & 초콜렛 & 23 & 74.19 & 251 & 그릇 & 19 & 61.29 \\
\hline 2 & 얌얌 & 30 & 96.77 & 127 & 배꼽 & 23 & 74.19 & 252 & 수건 & 19 & 61.29 \\
\hline 3 & 네 & 29 & 93.55 & 128 & 이 & 23 & 74.19 & 253 & 쓰레기통 & 19 & 61.29 \\
\hline 4 & 응 & 29 & 93.55 & 129 & 이빨 & 23 & 74.19 & 254 & 휴지통 & 19 & 61.29 \\
\hline 5 & 아니 & 29 & 93.55 & 130 & 안경 & 23 & 74.19 & 255 & 눈사람 & 19 & 61.29 \\
\hline 6 & 눈 & 29 & 93.55 & 131 & 약 & 23 & 74.19 & 256 & 달 & 19 & 61.29 \\
\hline 7 & 코 & 29 & 93.55 & 132 & 전화 & 23 & 74.19 & 257 & 시소 & 19 & 61.29 \\
\hline 8 & 안돼 & 29 & 93.55 & 133 & 치약 & 23 & 74.19 & 258 & 해 & 19 & 61.29 \\
\hline 9 & 엄마 & 29 & 93.55 & 134 & 미끄럼틀 & 23 & 74.19 & 259 & 햇빛 & 19 & 61.29 \\
\hline 10 & 할아버지 & 29 & 93.55 & 135 & 별 & 23 & 74.19 & 260 & 파이팅 & 19 & 61.29 \\
\hline 11 & 꽥꽥 & 28 & 90.32 & 136 & 하지마 & 23 & 74.19 & 261 & 바깥 & 19 & 61.29 \\
\hline 12 & 멍멍 & 28 & 90.32 & 137 & 먹어 & 23 & 74.19 & 262 & 회사 & 19 & 61.29 \\
\hline 13 & 칙칙폭폭 & 28 & 90.32 & 138 & 빼 & 23 & 74.19 & 263 & 다시 & 19 & 61.29 \\
\hline 14 & 공 & 28 & 90.32 & 139 & 줘 & 23 & 74.19 & 264 & 동생 & 19 & 61.29 \\
\hline 15 & 과자 & 28 & 90.32 & 140 & 자전거 & 22 & 70.97 & 265 & 삼촌 & 19 & 61.29 \\
\hline 16 & 까까 & 28 & 90.32 & 141 & 로봇 & 22 & 70.97 & 266 & 나와 & 19 & 61.29 \\
\hline 17 & 물 & 28 & 90.32 & 142 & 블록 & 22 & 70.97 & 267 & 닦아 & 19 & 61.29 \\
\hline 18 & 바나나 & 28 & 90.32 & 143 & 선물 & 22 & 70.97 & 268 & 봐 & 19 & 61.29 \\
\hline 19 & 빵 & 28 & 90.32 & 144 & 장난감 & 22 & 70.97 & 269 & 해 & 19 & 61.29 \\
\hline 20 & 머리 & 28 & 90.32 & 145 & 기린 & 22 & 70.97 & 270 & 간지러워 & 19 & 61.29 \\
\hline 21 & 발 & 28 & 90.32 & 146 & 닭 & 22 & 70.97 & 271 & 같아 & 19 & 61.29 \\
\hline 22 & 胘 & 28 & 90.32 & 147 & 벌 & 22 & 70.97 & 272 & 똑같아 & 19 & 61.29 \\
\hline 23 & 빠이빠이 & 28 & 90.32 & 148 & 단추 & 22 & 70.97 & 273 & 귀여워 & 19 & 61.29 \\
\hline 24 & 또 & 28 & 90.32 & 149 & 베개 & 22 & 70.97 & 274 & 더러워 & 19 & 61.29 \\
\hline 25 & 아빠 & 28 & 90.32 & 150 & 케이크 & 22 & 70.97 & 275 & 더워 & 19 & 61.29 \\
\hline 26 & 할머니 & 28 & 90.32 & 151 & 똥꼬 & 22 & 70.97 & 276 & 맛있어 & 19 & 61.29 \\
\hline 27 & 똑똑 & 27 & 87.10 & 152 & 팔 & 22 & 70.97 & 277 & 시끄러워 & 19 & 61.29 \\
\hline 28 & 야옹 & 27 & 87.10 & 153 & 빗 & 22 & 70.97 & 278 & 오토바이 & 18 & 58.06 \\
\hline 29 & 어흥 & 27 & 87.10 & 154 & 숟가락 & 22 & 70.97 & 279 & 트럭 & 18 & 58.06 \\
\hline 30 & 음매 & 27 & 87.10 & 155 & 시계 & 22 & 70.97 & 280 & 동물 & 18 & 58.06 \\
\hline 31 & 차 & 27 & 87.10 & 156 & 우산 & 22 & 70.97 & 281 & 목걸이 & 18 & 58.06 \\
\hline 32 & 자동차 & 27 & 87.10 & 157 & 그네 & 22 & 70.97 & 282 & 운동화 & 18 & 58.06 \\
\hline 33 & 새 & 27 & 87.10 & 158 & 불 & 22 & 70.97 & 283 & 주머니 & 18 & 58.06 \\
\hline 34 & 고기 & 27 & 87.10 & 159 & 만세 & 22 & 70.97 & 284 & 팬티 & 18 & 58.06 \\
\hline 35 & 딸기 & 27 & 87.10 & 160 & 빨리 & 22 & 70.97 & 285 & 부억 & 18 & 58.06 \\
\hline 36 & 사과 & 27 & 87.10 & 161 & 하나 & 22 & 70.97 & 286 & 감자 & 18 & 58.06 \\
\hline 37 & 사탕 & 27 & 87.10 & 162 & 사랑해 & 22 & 70.97 & 287 & 생선 & 18 & 58.06 \\
\hline 38 & 배 & 27 & 87.10 & 163 & 와 & 22 & 70.97 & 288 & 고추 & 18 & 58.06 \\
\hline 39 & 손 & 27 & 87.10 & 164 & 울어 & 22 & 70.97 & 289 & 등 & 18 & 58.06 \\
\hline 40 & 입 & 27 & 87.10 & 165 & 자 & 22 & 70.97 & 290 & 청소기 & 18 & 58.06 \\
\hline 41 & 안녕 & 27 & 87.10 & 166 & 깜깜해 & 22 & 70.97 & 291 & 카메라 & 18 & 58.06 \\
\hline 42 & 응가 & 27 & 87.10 & 167 & 매워 & 22 & 70.97 & 292 & 구름 & 18 & 58.06 \\
\hline 43 & 똥 & 27 & 87.10 & 168 & 무서워 & 22 & 70.97 & 293 & 모래 & 18 & 58.06 \\
\hline 44 & 꿀꿀 & 26 & 83.87 & 169 & 밖 & 22 & 70.97 & 294 & 흙า & 18 & 58.06 \\
\hline 45 & 짹짹 & 26 & 83.87 & 170 & 나 & 22 & 70.97 & 295 & 조금 & 18 & 58.06 \\
\hline 46 & 기차 & 26 & 83.87 & 171 & 여기 & 22 & 70.97 & 296 & 고모 & 18 & 58.06 \\
\hline
\end{tabular}


3. 24-30개월 아동 (Continued)

\begin{tabular}{|c|c|c|c|c|c|c|c|c|c|c|c|}
\hline & & $N$ & $\%$ & & & $\mathrm{~N}$ & $\%$ & & & $N$ & $\%$ \\
\hline 47 & 책 & 26 & 83.87 & 172 & 버스 & 21 & 67.74 & 297 & 오빠 & 18 & 58.06 \\
\hline 48 & 돼지 & 26 & 83.87 & 173 & 소방차 & 21 & 67.74 & 298 & 기다려 & 18 & 58.06 \\
\hline 49 & 물고기 & 26 & 83.87 & 174 & 헬리콥터 & 21 & 67.74 & 299 & 넣어 & 18 & 58.06 \\
\hline 50 & 코끼리 & 26 & 83.87 & 175 & 개 & 21 & 67.74 & 300 & 놀아 & 18 & 58.06 \\
\hline 51 & 호랑이 & 26 & 83.87 & 176 & 개구리 & 21 & 67.74 & 301 & 달려 & 18 & 58.06 \\
\hline 52 & 가방 & 26 & 83.87 & 177 & 화장실 & 21 & 67.74 & 302 & 도와 & 18 & 58.06 \\
\hline 53 & 기저귀 & 26 & 83.87 & 178 & 옥수수 & 21 & 67.74 & 303 & 벗어 & 18 & 58.06 \\
\hline 54 & 바지 & 26 & 83.87 & 179 & 토마토 & 21 & 67.74 & 304 & 불어 & 18 & 58.06 \\
\hline 55 & 계란 & 26 & 83.87 & 180 & 호박 & 21 & 67.74 & 305 & 사 & 18 & 58.06 \\
\hline 56 & 고구마 & 26 & 83.87 & 181 & 비누 & 21 & 67.74 & 306 & 씻어 & 18 & 58.06 \\
\hline 57 & 아이스크림 & 26 & 83.87 & 182 & 쓰레기 & 21 & 67.74 & 307 & 열어 & 18 & 58.06 \\
\hline 58 & 우유 & 26 & 83.87 & 183 & 눈 & 21 & 67.74 & 308 & 올라가 & 18 & 58.06 \\
\hline 59 & 컵 & 26 & 83.87 & 184 & 양치 & 21 & 67.74 & 309 & 읽어 & 18 & 58.06 \\
\hline 60 & 아기 & 26 & 83.87 & 185 & 병원 & 21 & 67.74 & 310 & 찾아 & 18 & 58.06 \\
\hline 61 & 아가 & 26 & 83.87 & 186 & 언니 & 21 & 67.74 & 311 & 괜찮아 & 18 & 58.06 \\
\hline 62 & 가 & 26 & 83.87 & 187 & 이모 & 21 & 67.74 & 312 & 예뻐 & 18 & 58.06 \\
\hline 63 & 이거 & 26 & 83.87 & 188 & 친구 & 21 & 67.74 & 313 & 작아 & 18 & 58.06 \\
\hline 64 & 인형 & 25 & 80.65 & 189 & 누구 & 21 & 67.74 & 314 & 커 & 18 & 58.06 \\
\hline 65 & 풍선 & 25 & 80.65 & 190 & 나가 & 21 & 67.74 & 315 & 위 & 18 & 58.06 \\
\hline 66 & 고양이 & 25 & 80.65 & 191 & 내려 & 21 & 67.74 & 316 & 공룡 & 17 & 54.84 \\
\hline 67 & 곰 & 25 & 80.65 & 192 & 누워 & 21 & 67.74 & 317 & 장갑 & 17 & 54.84 \\
\hline 68 & 나비 & 25 & 80.65 & 193 & 뽀뽀해 & 21 & 67.74 & 318 & 치마 & 17 & 54.84 \\
\hline 69 & 오리 & 25 & 80.65 & 194 & 일어나 & 21 & 67.74 & 319 & 목욕탕 & 17 & 54.84 \\
\hline 70 & 토끼 & 25 & 80.65 & 195 & 일어서 & 21 & 67.74 & 320 & 창문 & 17 & 54.84 \\
\hline 71 & 모자 & 25 & 80.65 & 196 & 많아 & 21 & 67.74 & 321 & 밤 & 17 & 54.84 \\
\hline 72 & 신 & 25 & 80.65 & 197 & 무거워 & 21 & 67.74 & 322 & 복숭아 & 17 & 54.84 \\
\hline 73 & 신발 & 25 & 80.65 & 198 & 배고파 & 21 & 67.74 & 323 & 오렌지 & 17 & 54.84 \\
\hline 74 & 의자 & 25 & 80.65 & 199 & 추워 & 21 & 67.74 & 324 & 몸 & 17 & 54.84 \\
\hline 75 & 텔레비전 & 25 & 80.65 & 200 & 유모차 & 20 & 64.52 & 325 & 입술 & 17 & 54.84 \\
\hline 76 & 달걀 & 25 & 80.65 & 201 & 종이 & 20 & 64.52 & 326 & 돈 & 17 & 54.84 \\
\hline 77 & 치즈 & 25 & 80.65 & 202 & 거북이 & 20 & 64.52 & 327 & 의사 & 17 & 54.84 \\
\hline 78 & 포도 & 25 & 80.65 & 203 & 벌레 & 20 & 64.52 & 328 & 그려 & 17 & 54.84 \\
\hline 79 & 귀 & 25 & 80.65 & 204 & 양 & 20 & 64.52 & 329 & 넘어져 & 17 & 54.84 \\
\hline 80 & 칫솔 & 25 & 80.65 & 205 & 원숭이 & 20 & 64.52 & 330 & 다쳐 & 17 & 54.84 \\
\hline 81 & 나무 & 25 & 80.65 & 206 & 참새 & 20 & 64.52 & 331 & 때려 & 17 & 54.84 \\
\hline 82 & 비 & 25 & 80.65 & 207 & 계단 & 20 & 64.52 & 332 & 뛰어 & 17 & 54.84 \\
\hline 83 & 돼 & 25 & 80.65 & 208 & 소파 & 20 & 64.52 & 333 & 마셔 & 17 & 54.84 \\
\hline 84 & 선생님 & 25 & 80.65 & 209 & 귤 & 20 & 64.52 & 334 & 만들어 & 17 & 54.84 \\
\hline 85 & 배 & 24 & 77.42 & 210 & 김치 & 20 & 64.52 & 335 & 몰라 & 17 & 54.84 \\
\hline 86 & 비행기 & 24 & 77.42 & 211 & 콩 & 20 & 64.52 & 336 & 부어 & 17 & 54.84 \\
\hline 87 & 크레파스 & 24 & 77.42 & 212 & 목 & 20 & 64.52 & 337 & 붙여 & 17 & 54.84 \\
\hline 88 & 개미 & 24 & 77.42 & 213 & 그림 & 20 & 64.52 & 338 & 비켜 & 17 & 54.84 \\
\hline 89 & 말 & 24 & 77.42 & 214 & 젓가락 & 20 & 64.52 & 339 & 신어 & 17 & 54.84 \\
\hline 90 & 사자 & 24 & 77.42 & 215 & 칼 & 20 & 64.52 & 340 & 웃어 & 17 & 54.84 \\
\hline 91 & 소 & 24 & 77.42 & 216 & 휴지 & 20 & 64.52 & 341 & 잘라 & 17 & 54.84 \\
\hline
\end{tabular}

(Continued to the next page) 
3. 24-30개월 아동 (Continued)

\begin{tabular}{|c|c|c|c|c|c|c|c|c|c|c|c|}
\hline & & $N$ & $\%$ & & & $N$ & $\%$ & & & $N$ & $\%$ \\
\hline 92 & 양말 & 24 & 77.42 & 217 & 돌 & 20 & 64.52 & 342 & 잡아 & 17 & 54.84 \\
\hline 93 & 옷 & 24 & 77.42 & 218 & 풀 & 20 & 64.52 & 343 & 차 & 17 & 54.84 \\
\hline 94 & 꼬까 & 24 & 77.42 & 219 & 하늘 & 20 & 64.52 & 344 & 밤 & 17 & 54.84 \\
\hline 95 & 문 & 24 & 77.42 & 220 & 목욕 & 20 & 64.52 & 345 & 저기 & 17 & 54.84 \\
\hline 96 & 김 & 24 & 77.42 & 221 & 슈퍼마켓 & 20 & 64.52 & 346 & 풀 & 16 & 51.61 \\
\hline 97 & 수박 & 24 & 77.42 & 222 & 아저씨 & 20 & 64.52 & 347 & 세탁기 & 16 & 51.61 \\
\hline 98 & 주스 & 24 & 77.42 & 223 & 어디 & 20 & 64.52 & 348 & 피아노 & 16 & 51.61 \\
\hline 99 & 다리 & 24 & 77.42 & 224 & 꺼내 & 20 & 64.52 & 349 & 감 & 16 & 51.61 \\
\hline 100 & 얼굴 & 24 & 77.42 & 225 & 닫아 & 20 & 64.52 & 350 & 땅콩 & 16 & 51.61 \\
\hline 101 & 엉덩이 & 24 & 77.42 & 226 & 던져 & 20 & 64.52 & 351 & 쌀 & 16 & 51.61 \\
\hline 102 & 포크 & 24 & 77.42 & 227 & 앉아 & 20 & 64.52 & 352 & 얼음 & 16 & 51.61 \\
\hline 103 & 고마워 & 24 & 77.42 & 228 & 입어 & 20 & 64.52 & 353 & 요구르트 & 16 & 51.61 \\
\hline 104 & 쉬 & 24 & 77.42 & 229 & 좋아해 & 20 & 64.52 & 354 & 발톱 & 16 & 51.61 \\
\hline 105 & 놀이터 & 24 & 77.42 & 230 & 타 & 20 & 64.52 & 355 & 턱 & 16 & 51.61 \\
\hline 106 & 집 & 24 & 77.42 & 231 & 있어 & 20 & 64.52 & 356 & 피 & 16 & 51.61 \\
\hline 107 & 더 & 24 & 77.42 & 232 & 졸려 & 20 & 64.52 & 357 & 지갑 & 16 & 51.61 \\
\hline 108 & 많이 & 24 & 77.42 & 233 & 차 & 20 & 64.52 & 358 & 바다 & 16 & 51.61 \\
\hline 109 & 무엇 & 24 & 77.42 & 234 & 불자동차 & 19 & 61.29 & 359 & 아파트 & 16 & 51.61 \\
\hline 110 & 뭐 & 24 & 77.42 & 235 & 택시 & 19 & 61.29 & 360 & 너무 & 16 & 51.61 \\
\hline 111 & 꺼 & 24 & 77.42 & 236 & 비누방울 & 19 & 61.29 & 361 & 공주 & 16 & 51.61 \\
\hline 112 & 안아 & 24 & 77.42 & 237 & 뱀 & 19 & 61.29 & 362 & 가져 & 16 & 51.61 \\
\hline 113 & 안해 & 24 & 77.42 & 238 & 악어 & 19 & 61.29 & 363 & 걸어 & 16 & 51.61 \\
\hline 114 & 뜨거워 & 24 & 77.42 & 239 & 쥐 & 19 & 61.29 & 364 & 둬 & 16 & 51.61 \\
\hline 115 & 실어 & 24 & 77.42 & 240 & 펭귄 & 19 & 61.29 & 365 & 들어가 & 16 & 51.61 \\
\hline 116 & 아파 & 24 & 77.42 & 241 & 하마 & 19 & 61.29 & 366 & 말해 & 16 & 51.61 \\
\hline 117 & 없어 & 24 & 77.42 & 242 & 잠바 & 19 & 61.29 & 367 & 발라 & 16 & 51.61 \\
\hline 118 & 좋아 & 24 & 77.42 & 243 & 침대 & 19 & 61.29 & 368 & 숨어 & 16 & 51.61 \\
\hline 119 & 연필 & 23 & 74.19 & 244 & 떡 & 19 & 61.29 & 369 & 올려 & 16 & 51.61 \\
\hline 120 & 크레용 & 23 & 74.19 & 245 & 커피 & 19 & 61.29 & 370 & 치워 & 16 & 51.61 \\
\hline 121 & 냉장고 & 23 & 74.19 & 246 & 머리카락 & 19 & 61.29 & 371 & 혼나 & 16 & 51.61 \\
\hline 122 & 방 & 23 & 74.19 & 247 & 무릎 & 19 & 61.29 & 372 & 높아 & 16 & 51.61 \\
\hline 123 & 이불 & 23 & 74.19 & 248 & 손가락 & 19 & 61.29 & 373 & 맛없어 & 16 & 51.61 \\
\hline 124 & 국 & 23 & 74.19 & 249 & 어깨 & 19 & 61.29 & 374 & 빨라 & 16 & 51.61 \\
\hline 125 & 당근 & 23 & 74.19 & 250 & 가위 & 19 & 61.29 & 375 & 앞 & 16 & 51.61 \\
\hline
\end{tabular}

$75 \%$ 이상 아동에게서 보고된 어휘에는 음영 처리하였음. 


\section{국문초록}

\section{2-30개월 아동의 초기 어휘에 나타난 음운 특성}

하승희'(교수, 제1저자, 교신저자) · 피민경'(학생)

'한림대학교 언어청각학부, 청각언어연구소, ${ }^{2}$ 한림대학교 대학원 언어병리청각학과

배경 및 목적: 초기 언어습득 과정에서 관찰되는 음운과 어휘 간의 관계를 살펴보고자 본 연구는 한국판 맥아더-베이츠 의사소통발달 평가(K M-B CDI)에 포함된 표현 어휘의 음운 특성을 분석하였다. 또한 12-30개월 일반 한국 아동이 습득한 표현 어휘 목록에 나타난 음운 특성을 살펴보았다. 방법: $\mathrm{KM}-\mathrm{B} \mathrm{CDI}$ 에 포함된 어휘를 음운 전사한 뒤에 말소리 빈도, 낱말의 첫소리 유형, 낱말 구조를 살펴보았 다. 세 월령(12-17개월, 18-23개월, 24-30개월)대로 나눈 193명 아동의 보호자를 대상으로 K M-B CDI를 실시하였다. 아동의 표현 어휘 를 음운 전사하여 월령 집단별로 말소리 빈도, 낱말의 첫 소리 유형, 낱말 구조를 살펴보았다. 결과: K M-B CDI에 포함된 어휘에서는 2 음절과 1음절의 CVCV, CVC 구조의 낱말 비율이 가장 높았다. 말소리는/ㄹ, ᄀᄀ, ᄂ, ㅁ, ㄱ, I/가 높은 비율을 차지하였다. 12-17개월의 $75 \%$ 아동은 /ㅁ, 삐/가 포함되고 모음이나 비음으로 시작하는 낱말만을 산출하였다. 24 개월 미만의 아동이 가장 빈번하게 산출하는 낱말 구조는 VCV였다. 아동이 연령이 증가하고 표현 어휘가 증가함에 따라 말소리와 낱말 구조 목록과 파열음으로 시작하는 낱말의 비율이 증가하였다. 논의 및 결론: 본 연구는 초기 어휘의 음운 특성을 살펴봄으로써 초기 언어발달 단계에서부터 지연·문제를 보이는 아동을 위해음운과 어휘 영역을 동시에 고려한 목표 어휘를 선정할 수 있는 근거를 제안하였다.

핵심어: 초기 어휘, 음운 특성, 부모 보고

\section{참고문헌}

김영태, 김경희, 윤혜련, 김화수(2003). 영유아 언어발달 검사(SELSI). 서울: 도서출판 특수교육.

박혜진, 배소영(2003). 청각장애 유아의 어휘 발달. 언어청각장애연구, 8, 66-81.

배소영, 곽금주(2011). 한국판 맥아더-베이츠 의사소통발달평가(K M-B CDI). 서울: 마인드프레스.

배소영, 곽금주, 김근영, 정경희, 김효정(2009). 다문화가정 어머니와 발달지원자 설문을 통해 본 아동의 언어환경 및 언어발달 실태. 언어치료연구, 18 , 165-184.

배희숙, 김현기(2010). 영유아초기어휘 검사도구 [MB CDI-K] 의 개념 분포 특성 연구. 언어치료연구, 19, 89-107.

신지연, 이윤경(2008). 어휘체크리스트를 이용한 자폐 범주성 장애 유아의 표현어휘특성. 자폐성장애연구, 8, 143-154

양순임(2005). 한국어음절말 폐쇄음에 대한음향 및 청각 음성학적 연구. 한글, 269, 77-100.

윤미선, 김정미, 김수진(2013). 자발화 문맥에서의 단어단위 음운 평가. 언어치료연구, 22, 69-85.

장혜성, 서소정, 하지영(2008). 영아선별 교육진단검사(DEP). 서울: 학지사.

피민경, 하승희(2017). 구개열 아동, 말 늦은 아동, 일반 아동의 초기 어휘에 나타난 음운 특성. Communication Sciences \& Disorders, 22, 328-340 피민경, 하승희(2018). 18-30개월 아동의 자발화에 나타난음운, 어휘, 문법 능력의 관계. Communication Sciences \& Disorders, 23, 1-10.

하승희, 설아영, 배소영(2014). 일반 영유아의 초기 발성 발달 연구. 말소리와음성과학, 6, 161-169.

하승희, 피민경(2016). 18-30개월 한국 아동의 자발화에 나타난자음 빈도와 어절 첫소리 특성. Communication Sciences \& Disorders, 21, 567-579. 